\title{
Data Processing Payment of Educational Guidance Contributions at Al Ihsan Pamarican High School, Ciamis Regency
}

\author{
Lady Gardi
}

Program Studi Teknik Informatika, Universitas Galuh Ciamis, Indonesia

\begin{tabular}{|c|c|}
\hline Article Info & ABSTRACT \\
\hline Article history: & The use of computer technology, especially in terms of data processing, \\
\hline $\begin{array}{l}\text { Received: } 06 / 04 / 2021 \\
\text { Revised: } 13 / 05 / 2021 \\
\text { Accepted: 02/06/2021 } \\
\text { Available online 30/06/2021 }\end{array}$ & $\begin{array}{l}\text { is currently very necessary, both for the benefit of individuals and for } \\
\text { an agency, including the payment system for the Educational } \\
\text { Development Contribution (SPP) at SMK Al-Ihsan Pamarican. The } \\
\text { tuition payment process at Al-Ihsan Pamarican Vocational School } \\
\text { requires a recording, processing, storage and report on students who }\end{array}$ \\
\hline & $\begin{array}{l}\text { make payments. The problems mentioned above, the authors create a } \\
\text { payment data processing system that aims to build a payment data }\end{array}$ \\
\hline $\begin{array}{l}\text { Learning Media } \\
\text { Junior High School, } \\
\text { Websites. }\end{array}$ & $\begin{array}{l}\text { processing of educational assistance donations that is easy to use, and } \\
\text { can be relied on and ensures the availability of data. The result of this } \\
\text { final project is in the form of a payment system that can be } \\
\text { implemented at the Al-Ihsan Pamarican Vocational School, or other } \\
\text { educational institutions. which can eventually be used for the storage, } \\
\text { processing, and reporting of computerized payment data. With the } \\
\text { implementation of a computerized system or application program, in } \\
\text { providing services and performance, tuition payments can run well, } \\
\text { and can speed up data information services for parties in need, such as } \\
\text { students, the finance department and reports to the principal. }\end{array}$ \\
\hline
\end{tabular}

This is an open access article under theCC BY-NClicense.

\section{Corresponding Author:}

Lady Gardi,

Program Studi Teknik Informatika, Universitas Galuh Ciamis, Indonesia Email: ladigardi43@gmail.com

\section{Introduction}

The use of computer technology, especially in terms of data processing, is currently very necessary, both for the benefit of individuals and for an agency, including the SPP payment system at SMK Al-Ihsan Pamarican. The process of paying tuition fees at SMK AL-Ihsan Pamarican requires a recording, processing, storage and reporting of students who pay tuition fees(Nurajizah, 2015).

One of the problems that exist at SMK Al-Ihsan Pamarican is that data processing is still carried out in a simple way, namely using spreadsheet application software, where officers have to look for student data one by one who will make tuition payments, besides that officers also have to make reports about students who have pay tuition every day. Where in the report it is stated how many students have made tuition payments and how much money has come in. To make the report, the officer has to look again for the data of students who have paid tuition and immediately record it and calculate how much money comes in(ANTO, 2017). So the process takes a long time. With this simple method, it is possible for errors to occur in data entry, calculations and in making reports(Sunarti, 2016). 


\section{Method}

\subsection{Method of collecting data}

The data collection technique used is by conducting observations, interviews and literature studies. Observation or observation involves all senses (sight, hearing, smell, smell and taste). What was observed was how the data processing and data flow occurred at the research site. Observation is centered in the Administration room and the Teacher's room, which is where the object of research will be carried out (CHRISNA, 2016). The second way is to conduct interviews with subjects related to the data. Interviews were conducted directly (face to face) with an unstructured interview technique. Because it is unstructured, interviewers can freely dig up information from respondents. The interviewer can also be more flexible in asking questions according to the conditions and flow of the conversation (HANAFiyah, nd). The third way is to conduct a literature review, namely by reviewing several library sources such as books, papers, notes, articles related to the problem under study and a summary that supports the research can be drawn.

\subsection{Software Development Method}

In software development using the waterfall model. The name of this model is actually "Linear Sequential Model". This model is often referred to as the "Classic Life Cycle" or the waterfall model. This model is a model that appeared for the first time around 1970 so it is often considered ancient, but the model is widely used in Software Engineering (SE). This model takes a systematic and sequential approach starting from the level of system requirements and then going to the analysis, design, coding, testing or verification, and maintenance stages. It is called a waterfall because the stages that are passed must wait for the completion of the previous stage and run sequentially (Senewe, Sinsuw, \& Tulenan, 2015). For example, the design stage must wait for the previous stage, namely the requirements stage. Apart from being easy to apply using this model, the advantage of this model is that when all system requirements can be defined completely, explicitly, and correctly at the beginning of the project, SE can run well and without problems. Although often the system requirements are not defined as explicitly as desired, but at least, the problem with the system requirements at the beginning of the project is more economical in terms of money (cheaper), effort, and less time wasted when compared to problems that arise in later stages (New, 2015).

\section{Results and Discussion}

\subsection{System Implementation}

1. Table Construction in Database

The table is made based on the ER diagram in the table design. Here is the table construction designed:

a. Student Data Table

\begin{tabular}{ccccc}
\multicolumn{5}{c}{ Table 1 Student Data Table } \\
\hline No & Field Name & Type & Size & Description \\
\hline 1 & NIS & Number & 9 & Student ID number \\
2 & Name & Text & 25 & Name Siawa \\
3 & Class & Text & 7 & Class \\
4 & place & Text & 25 & Place of birth \\
5 & Date & Date/Time & & Date of birth \\
6 & Parents' name & Text & 20 & Parents' name \\
7 & phone & Number & & Phone number \\
8 & Address & Text & 50 & Student Address \\
\hline
\end{tabular}

b. Payment Data Table 
Table 2 Payment Data Table

\begin{tabular}{ccccc}
\hline No & Field Name & Type & Size & Description \\
\hline 1 & No_SPP & Auto & 4 & Tuition Number \\
2 & NIS & Number & 9 & $\begin{array}{c}\text { Student Identification } \\
\text { Number }\end{array}$ \\
& & & & Student's name \\
3 & Name & Text & 25 & Class \\
4 & Class & Text & 7 & Payment Month \\
5 & Month & Date/Time & & Payment date \\
6 & Date & Date/Time & & Big Contribution \\
7 & Payment & Number & &
\end{tabular}

Description: The Payment Data Table is used to store data on students who have made tuition payments

\section{Input Design}

Design The input of this application is used as the basic material for making the layout design later, here is the input design.

a. Login design

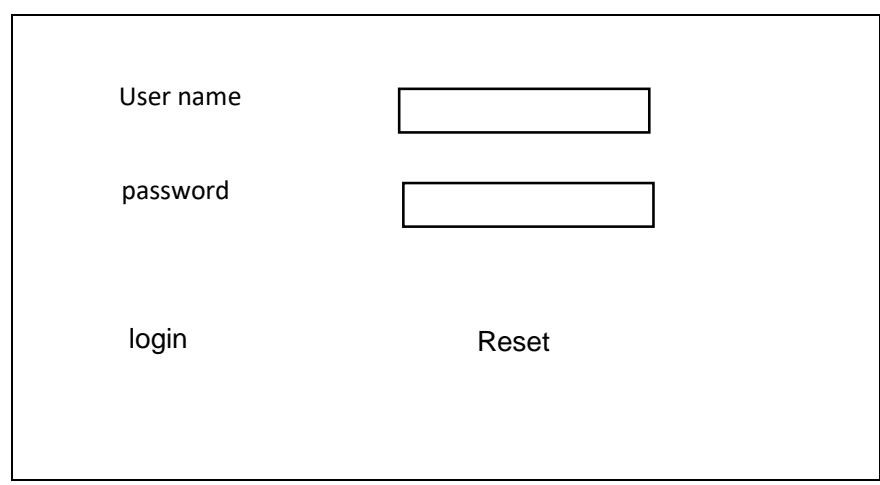

Figure 2.Login Design

b. Main page design

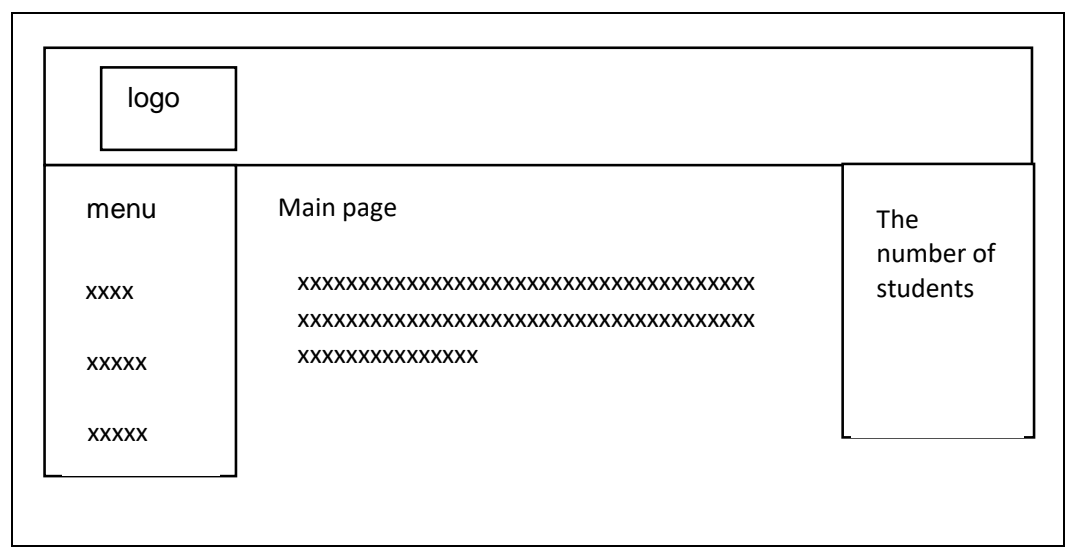

Figure 3. Main page 
c. Student form design

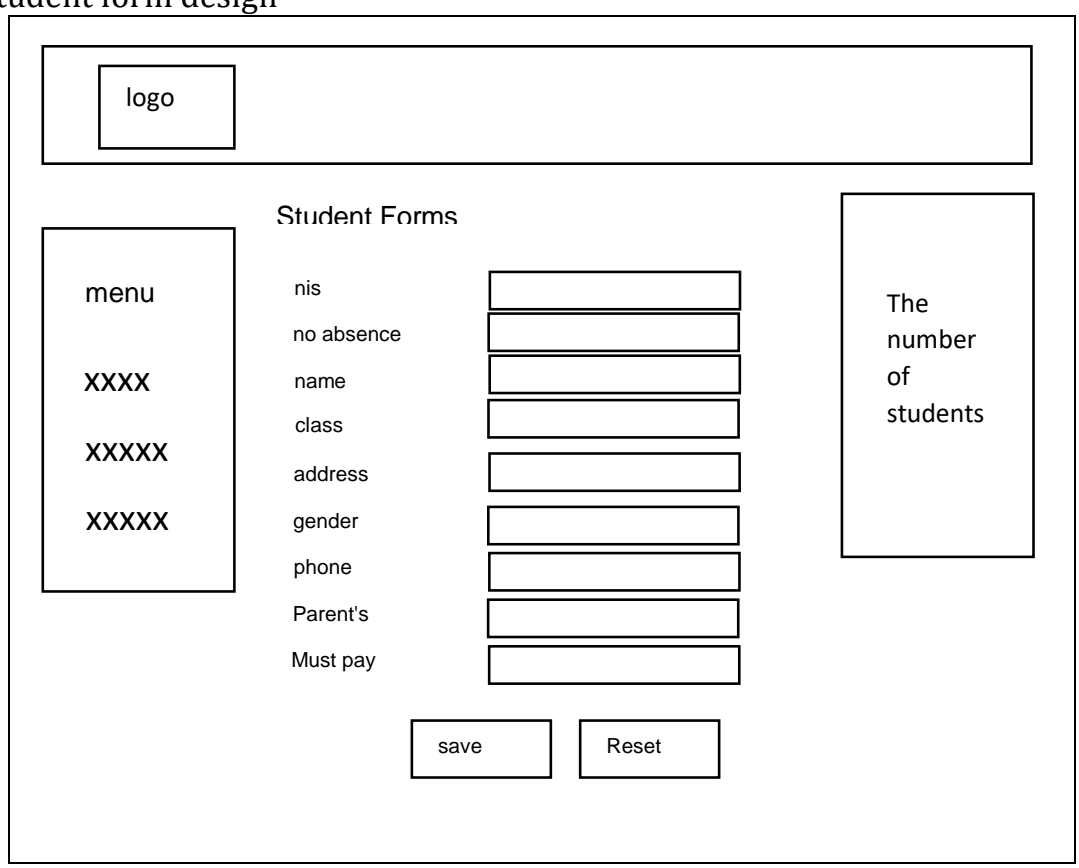

Figure 4. Student Form

d. Transaction form design

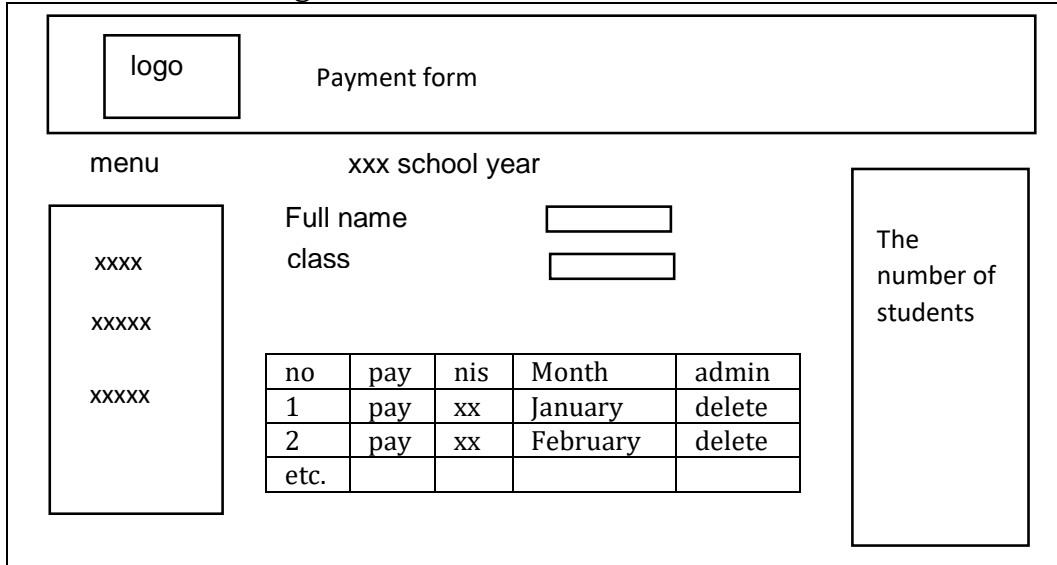

Figure 5. Transaction Form

\section{Conclusion}

There are several things that can be concluded from the results of research and making an application program, namely with this application program it can facilitate the process of making financial reports, both daily reports and monthly reports. This application program can provide information to parties who want data on students who have paid tuition fees. 


\section{Reference}

ANTO, D. S. (2017). Penerapan Teknologi Barcode pada Pengolahan Data Pembayaran Sumbangan Pembinaan Pendidikan (SPP). Jurnal Intra Tech, 1(2), 18-27.

Barus, A. F. (2015). Sistem Informasi Geografis Letak Komplek Perumahan Di Kota Palembang Dengan Menggunakan Arcview. Universitas Katolik Musi Charitas.

CHRISNA, R. (2016). TEKNIK WAWANCARA REPORTER HARIAN RADAR JEMBER DALAM MENCARI BERITA INVESTIGATIF. IAIN JEMBER.

HANAFIYAH, M. (n.d.). Pengaruh Pemodelan Tayangan "Hitam Putih" Terhadap Kemampuan Menulis Teks Wawancara Oleh siswa Kelas VIII SMP PAB 3 Saentis Percut Sei Tuan Tahun Pembelajaran 2016-2017.

Nurajizah, S. (2015). Sistem Informasi Perpustakaan Berbasis Web Dengan Metode Prototype: Studi Kasus Sekolah Islam Gema Nurani Bekasi. SNIT 2015, 1(1), 213-218.

Senewe, J., Sinsuw, A. A. E., \& Tulenan, V. (2015). Sistem Informasi Berbasis Web Studi Kasus Rusunawa Universitas Sam Ratulangi. Jurnal Teknik Elektro Dan Komputer, 4(5), 57-64.

Sunarti, S. (2016). Rancang Bangun Sistem Peminjaman Pada Koperasi Hortina Direktorat Jenderal Hortikultura Jakarta. IJCIT (Indonesian Journal on Computer and Information Technology), 1(1). 